\title{
Application of Capillary Electrophoresis to Anion Speciation in Soil Water Extracts: II. Arsenic
}

\author{
R. Naidu,* J. Smith, R. G. McLaren, D. P. Stevens, M. E. Sumner, and P. E. Jackson
}

\begin{abstract}
A method has been developed for the speciation of arsenic $\left(\mathrm{AsO}_{2}^{-}, \mathrm{AsO}_{4}^{3-}\right.$, and dimethylarsinic [DMA]) in natural soil solutions from contaminated sites in Australia. The separation of these anions was achieved by capillary zone electrophoresis (CZE) using a fused silica capillary (72-cm by $50-\mu \mathrm{m}$ i.d.) with a basic chromate buffer and on-column indirect $U V$ detection at $254 \mathrm{~nm}$. Method parameters, such as electrolyte $\mathrm{pH}$, run voltage, and capillary temperature were studied in order to establish suitable analytical conditions. The ideal separation for As(III) and DMA was achieved with a buffer $\mathrm{pH}$ of 8.0, a run voltage of $25 \mathrm{kV}$, and a capillary temperature of $30^{\circ} \mathrm{C}$. Under these conditions, $\mathbf{A s}(\mathrm{V})$ and orthophosphate ions comigrated. However, the use of a chromate buffer at $\mathrm{pH} 10$, a run voltage of 20 $\mathrm{kV}$, and capillary temperature of $20^{\circ} \mathrm{C}$ led to complete separation of $\mathrm{As}(\mathrm{V})$ and phosphate peaks. Results of these investigations together with recovery test data suggest that separation of the As species from soil solutions can be achieved in less than 5 min with detection limits of $0.50,0.10$, and $0.10 \mathrm{mg} \mathrm{L}^{-1}$ for $\mathrm{As}(\mathrm{III}), \mathrm{As}(\mathrm{V})$, and DMA, respectively.
\end{abstract}

$\mathbf{I}^{1}$ IS WELL ESTABLISHED that the toxicity of arsenic (As) is dependent on its chemical form. Arsenic is known to exist in natural soil and water environments in different oxidation states depending on the redox potential. Arsenite, As(III), is the most toxic of the common water-soluble species in environmental samples. The pentavalent species, $\mathrm{As}(\mathrm{V})$, is also relatively toxic, whereas the organoarsenic compounds such as the monomethyl arsinic acid (MMA) and DMA are much less toxic (Hodgson et al., 1988, p. 40-41). Speciation of As in natural samples is important in assessing exposure to toxic As compounds. Therefore, analytical methods that determine only the total amount of As present in samples do not adequately assess the danger of exposure. Moreover, a knowledge of the concentrations of As species is important in understanding the transport and biochemical processes involving As species in aquatic and soil water environments. Analytical data on As species, which have been difficult to quantify in natural soil and water samples, are not commonly found.

A number of instrumental techniques have been used to speciate As in the environment including ion chromatography (IC), high performance liquid chromatographyinductively coupled plasma mass spectrometry (HPLC-

R. Naidu and J. Smith, CSIRO Land and Water and the Cooperative Research Centre for Soil and Land Management, Private Mail Bag No. 2, Glen Osmond, South Australia 5064; R.G. McLaren, Soil, Plant and Ecological Sciences Division, P.O. Box 84, Lincoln Univ., Canterbury, New Zealand; D.P. Stevens, Dep. of Land and Water, Univ. of Adelaide, Waite Campus, Urrbrae, South Australia 5064 M.E. Sumner, Dep. of Crop and Plant Sciences, Univ. of Georgia, Athens, GA 30602; P. Jackson, Dionex Corporation, 1228 Titan Way, Sunnyvale, CA 94088-3606. Received 1 Dec. 1997. *Corresponding author (Ravi.Naidu@adl.clw.csiro.au).

Published in Soil Sci. Soc. Am. J. 64:122-128 (2000).
ICP-MS) (Thompson and Houk, 1986; Beauchemin et al., 1988), and IC coupled with ICP-MS (Sheppard et al., 1992). Speciation of As can also be achieved by supercritical fluid chromatography by complexing As(III) with bis(trifluoroethyl) dithiocarbamate (Laintz et al., 1992a,b). However, most of these methods are either difficult to perform, subject to interferences, or require expensive equipment.

Capillary zone electrophoresis (CZE) is a highly versatile analytical technique that is increasingly being used to speciate a wide variety of inorganic and organic species (Heckenberg et al., 1989; Jackson and Haddad, 1993; Jones and Jandik, 1991, 1992; Naidu, 1996; Naidu et al., 1998). This emerging technique allows for the rapid separation of charged compounds on the basis of differences in their electrophoretic mobilities. The more established technique of IC uses large volumes of mobile phase and requires a reasonably large sample size by comparison; on the other hand, CZE uses low volumes of electrolyte, typically achieves separations in $<5$ to 10 min, requires only nanoliters of sample, and the running costs are low. A number of investigators have previously reported the separation of $\mathrm{As}(\mathrm{III})$ and $\mathrm{As}(\mathrm{V})$ in standard solutions and spiked samples using CZE (e.g., Wildman et al., 1991; Morin et al., 1992). However, there are no reports in the literature on the speciation of As in soil water samples from contaminated sites. Most of the work reported in the literature (e.g., Morin et al., 1992) considers high concentrations of As that do not typify soil solution concentrations in contaminated soils. Information on the nature of As in soil solution and soil water extracts is important given that its toxicity to soil biota may vary with the nature of the species. Moreover, the mobility of As in soils may also vary with the nature of As species given that their partitioning to soil is dependent on their oxidation status. In this paper, we report the development of a new CZE method for the speciation of As in natural soil solution samples from contaminated sites in Australia.

\section{MATERIALS AND METHODS}

\section{Instrumentation}

A Waters Corporation (Milford, MA) model Quanta 4000 capillary ion analyzer equipped with a reversible-polarity power supply was used for the speciation and determination of As compounds. A fused silica capillary (72-cm by $50-\mu \mathrm{m}$ i.d.) was used to separate the As species. The detection window was located approximately $64 \mathrm{~cm}$ from the injection point of

Abbreviations: CZE, capillary zone electrophoresis; DMA, dimethylarsinic acid; HPLC, high performance liquid chromatography; IC, ion chromatography; ICP, inductively coupled plasma; MMA, monomethyl arsinic acid; MS, mass spectometry; RCF, relative centrifugal force. 
the capillary. Between each analysis, the capillary was flushed with buffer solution for $2 \mathrm{~min}$. Ultraviolet detection (indirect) was carried out at $254 \mathrm{~nm}$. The electropherograms were recorded and processed with Waters Milennium Chromatography Management Software. The capillary temperature and run voltage were varied between 20 to $35^{\circ} \mathrm{C}$ and 20 to $30 \mathrm{kV}$, respectively.

\section{Sample Introduction}

While a number of different modes of sample introduction are possible when using CZE, all injections in the present study were performed using hydrostatic injection. This involved (automatically) immersing the capillary in the sample, which is then raised to a height $10 \mathrm{~cm}$ above the running electrolyte level for $30 \mathrm{~s}$. Following this operation, the sample chamber lowers back to the original level, after which the capillary is removed from the sample. The loaded capillary is then immersed into the running electrolyte and the voltage applied. Prior to sample introduction, a 2 min capillary purge is performed to remove any late migrating peaks remaining from the previous sample, i.e., the water peak. This is accomplished by a vacuum $>0.08 \mathrm{MPa}$ applied to the receiving electrolyte vial.

\section{Soil Solutions}

Surface and subsurface field moist soil samples from cattle tick dip As contaminated sites from northern New South Wales, Australia, were used to isolate soil solution for the analysis of soluble As. Duplicate samples (at field moisture capacity) were centrifuged at $3000 \mathrm{rpm}$ (RCF 1075) for $2 \mathrm{~h}$ with a double jacket type centrifuge tube with an insert to collect soil solution. Soil solution (usually $2-5 \mathrm{~mL} / 200 \mathrm{~g}$ ) collected at the base of the tube in the collection vessel was decanted into another centrifuge tube and centrifuged at $15000 \mathrm{rpm}$ (RC 26890 ) for $90 \mathrm{~min}$. Following the high speed centrifugation, soil solution was passed through a Millipore $0.2-\mu \mathrm{m}$ nylon filter. Subsamples were used for $\mathrm{pH}$, electrical conductivity, speciation of As, and total chemical composition analyses. Arsenic in the soil solution was determined with hydride generation (Voth-Beach and Shrader, 1985).

\section{Chemicals and Reagents}

\section{Standard Solutions}

Commercially available sodium arsenite $\left(\mathrm{NaAsO}_{2}\right.$ of $99 \%$ purity), sodium arsenate $\left(\mathrm{Na}_{2} \mathrm{HAsO}_{4} \cdot 7 \mathrm{H}_{2} \mathrm{O}\right.$ of $99 \%$ purity), and dimethylarsinic acid (DMA of $98 \%$ purity) were used without further purification. $\mathrm{NaAsO}_{2}$ was the chemical used during the tick eradication process. Following dissolution in water and with aging (or time) arsenious acid that is formed during the solution process oxidizes to arsenic acid. For this reason, fresh solutions were prepared daily during the speciation study using capillary electrophoresis.

Because MMA of analytical grade purity was not available, a reagent grade solution was used with CZE to identify the potential for separation of the As species. However, quantitation of MMA was not attempted in this study.

Stock solutions of arsenic species $\left(100 \mathrm{mg} \mathrm{L}^{-1}\right)$ were prepared in Millipore (Bedford, MA) Milli-Q water and kept at $-4^{\circ} \mathrm{C}$ as a precaution against any degradation. Calibration solutions ranging in concentration from blank to $10 \mathrm{mg} \mathrm{L}^{-1}$ were prepared from the stock solution as required. Since natural soil water samples contain a range of anions including $\mathrm{Cl}$, $\mathrm{SO}_{4}, \mathrm{NO}_{3}$, and $\mathrm{H}_{2} \mathrm{PO}_{4}$, the effects of these ions on As speciation were also investigated.

\section{Electrolyte Buffer Solution}

Chromate-based electrolytes have been demonstrated to give good performance in CZE, in terms of detection sensitivity and peak efficiency for high mobility anions (Heckenberg et al, 1989). The chromate-based electrolyte used in this work was prepared from a chromate concentrate containing 100 mmol L ${ }^{-1} \mathrm{Na}_{2} \mathrm{CrO}_{4}$ (Mallinckrodt AR grade, Mallinckrodt, Inc., Chesterfield, $\mathrm{MO}$ ) and $0.69 \mathrm{mmol} \mathrm{L}^{-1} \mathrm{H}_{2} \mathrm{SO}_{4}$. Dilute acid is included to preadjust the electrolyte $\mathrm{pH}$ to $\sim 8.0$ when preparing the electrolyte buffer solution of $5 \mathrm{mmol} \mathrm{L}^{-1}$ chromate, in addition to $0.5 \mathrm{mmol} \mathrm{L^{-1 }}$ of a proprietary Waters electroosmotic flow (EOF) modifier (CIA-Pak OFM Anion$\mathrm{BT})$. The $\mathrm{pH}$ of the resulting solution was 7.65. Milli-Q water was used for all dilutions and apparatus rinsing. A $100 \mathrm{mmol} \mathrm{L}{ }^{-1} \mathrm{LiOH}$ solution was used for $\mathrm{pH}$ adjustment.

\section{RESULTS AND DISCUSSION Composition of Soil Solution}

The composition of soil solution varied considerably among the soils examined. For instance, $\mathrm{pH}$ of the soil solutions ranged from 4.5 to 6.5 (with one exception that had a $\mathrm{pH}>12$ ) while dissolved organic carbon (as reflected by absorbance at $290 \mathrm{~nm}$ ) was not detected in the soil solution. Typically, the concentrations of major cations and anions in the soil solution were generally high (Table 1). This was not surprising given that lime and phosphate were added during the pesticide stabilization process. The high concentration of $\mathrm{Na}$ ion is attributed to the nature of As pesticide used during the tick eradication process. Trace elements including $\mathrm{Zn}$, $\mathrm{Cu}$, and $\mathrm{Mn}$ were low in the soils and therefore these data are not presented here.

\section{Selection of Operating Conditions}

\section{Effect of Electrolyte pH}

The electrophoretic buffer solution $\mathrm{pH}$ had a significant effect on the separation of As species in standard solutions. When the instrument was run under the normal operating conditions (Heckenberg et al., 1989) for high mobility anions (20 kV run voltage, buffer $\mathrm{pH}$ of 8.13 and $20^{\circ} \mathrm{C}$ ), separation was achieved for all three As species under study. However, the detection sensitivity for $\mathrm{As}(\mathrm{III})$ was poor $\left(3 \mathrm{mg} \mathrm{\textrm {L } ^ { - 1 }}\right)$ compared with $\mathrm{As}(\mathrm{V})$ and DMA. Increasing buffer $\mathrm{pH}$ decreased migration times for all species. However, changes in migration time for $\mathrm{As}(\mathrm{V})(2.0-1.90 \mathrm{~min})$ and DMA (2.8 $2.65 \mathrm{~min}$ ) were not as pronounced as was observed for As(III) $(4.80$ - 2.70 min).

Because As species under study are polyprotic acids,

Table 1. Descriptive statistics for soil solution composition of soils $(n=22)$ used in the present study.

\begin{tabular}{|c|c|c|c|c|c|}
\hline Measurement & Mean & SD & Min & Max & CV \\
\hline & \multicolumn{4}{|c|}{$\mathbf{m g} \mathbf{L}^{-1}$} & $\%$ \\
\hline $\mathrm{Ca}$ & 7.4 & 5.8 & 0.6 & 24.7 & 10.4 \\
\hline $\mathbf{K}$ & 4.2 & 5.4 & 0.3 & 20.0 & 15.3 \\
\hline Mg & 1.8 & 1.6 & 0.1 & 5.3 & 6.7 \\
\hline $\mathrm{Na}$ & 3.5 & 2.1 & 1.1 & 8.8 & 6.8 \\
\hline $\mathbf{P}$ & 3.5 & 2.3 & 0.0 & 7.5 & 12.4 \\
\hline $\mathbf{S}$ & 4.1 & 2.6 & 0.4 & 9.8 & 5.8 \\
\hline pH & 5.78 & 0.42 & 4.48 & 6.99 & 1.2 \\
\hline
\end{tabular}




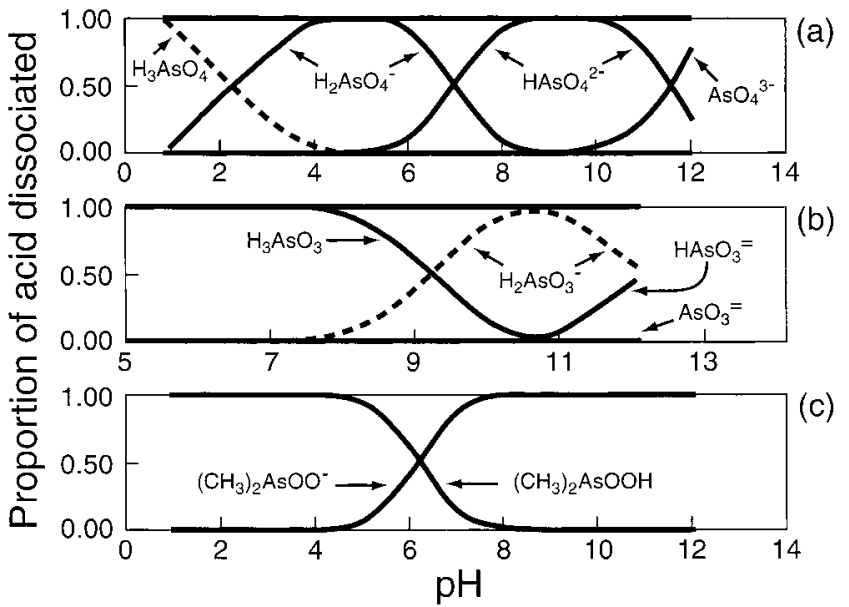

Fig. 1. Effect of solution $\mathrm{pH}$ on the proportion of acid dissociated based on the acid $\mathbf{p K}$ values.

their apparent charge is dependent on both their $\mathrm{pK}_{\mathrm{a}}$ and carrier electrolyte $\mathrm{pH}$ values. Changes in ionic charge with changing $\mathrm{pH}$ will influence the mobility of the analyte species. Increasing $\mathrm{pH}$ will enhance the ionization of arsenic, arsenous, and dimethylarsinic acids. However, the extent of ionization varies considerably among the acids considered in the present study (Fig. 1). The deprotonation of acids leads to the formation of ions that vary considerably in their charge and in their ionic size to charge ratio. Such differences lead to vastly different mobilities. The analyte mobility in CZE is described by:

$$
\mu=\mu_{m}+\mu_{0},
$$

where $\mu=$ mobility of the analyte in $\mathrm{cm} \mathrm{s}^{-1}, \mu_{\mathrm{m}}=$ electrophoretic mobility, and $\mu_{\mathrm{o}}=$ electroosmotic mobility.

Analyte mobility is the most important parameter determining separation efficiency and selectivity. Factors such as $\mathrm{pH}$, ionic strength, potential drop across the capillary, and the temperature can be manipulated to improve separations through changes in analyte mobility. Because the composition of electrolyte, temperature, and the potential drop across the capillary is constant during a CZE separation, it is likely that the marked differences in the migration time is related to the dissociation of the protonated As species. The DMA is fully dissociated at $\mathrm{pH} 8$ (Fig. 1). This explains the observed constant migration time. Similar to DMA, $97 \%$ of arsenic acid is present in ionic form although the nature and proportion of the conjugate acid-base pair $\left(\mathrm{H}_{3} \mathrm{AsO}_{4} / \mathrm{H}_{2} \mathrm{AsO}_{4}^{-}\right.$and $\mathrm{H}_{2} \mathrm{AsO}_{4}^{-} / \mathrm{HAsO}_{4}^{=}$etc) varies with increasing $\mathrm{pH}$. For instance at $\mathrm{pH} 5$, all the neutral molecule is dissociated into the diprotic form while at $\mathrm{pH} 10,97 \%$ is present as $\mathrm{HAsO}_{4}^{=}$and only $3 \%$ as $\mathrm{AsO}_{4}{ }^{3-}$ (Fig. 1). Therefore for these acids we expect a constant migration time. In contrast to $\mathrm{As}(\mathrm{V})$ and DMA, the migration time for $\mathrm{As}(\mathrm{III})$ is much longer at $\mathrm{pH} 8$ because arsenious acid is largely present as uncharged species (94\%) at pH 8 (Fig. 1).

\section{Effect of Run Voltage and Capillary Temperature}

When As(III) was detected using the normal operating conditions for high mobility anions (Waters CE manual), the detection, sensitivity and reproducibility were poor compared with $\mathrm{As}(\mathrm{V})$ and DMA. Changes in capillary temperature and run voltage affect several physical parameters such as viscosity, dielectric constant, dissociation constant of the ionizable species, and $\mathrm{pH}$; these in turn affect the electroosmotic flow and the electrophoretic mobility of the analyte species. Both the run voltage and the capillary temperature were varied to investigate changes in the migration of As species. The results (Fig. 2) show that increasing the run voltage (a) and the temperature (b) reduced the anion migration time compared with those achieved under normal operating conditions with little loss in resolution. Observations over a range of temperatures and run voltages showed that operating conditions of $20 \mathrm{kV}, 20^{\circ} \mathrm{C}$, and a buffer $\mathrm{pH}$ of 11 gave the best overall separation for the standard As solution. However, the electropherogram obtained using these conditions consistently produced high background noise, making the detection of As(III) difficult at concentrations below $3 \mathrm{mg} \mathrm{L}^{-1}$. Further studies varying $\mathrm{pH}$, run voltage, and temperature revealed that a buffer $\mathrm{pH}$ of 8.13 and operating conditions of 25 $\mathrm{kV}, 30^{\circ} \mathrm{C}$ were the most effective conditions for determination of the As species. The electropherograms obtained for $\mathrm{As}(\mathrm{III}), \mathrm{As}(\mathrm{V})$, and DMA at different $\mathrm{pH}$ values ([As] $=4 \mathrm{mg} \mathrm{L}^{-1}$ ) using operating conditions of $25 \mathrm{kV}, 30^{\circ} \mathrm{C}$ are presented in Fig. 3. These conditions were then applied to the speciation of As in soil water samples.
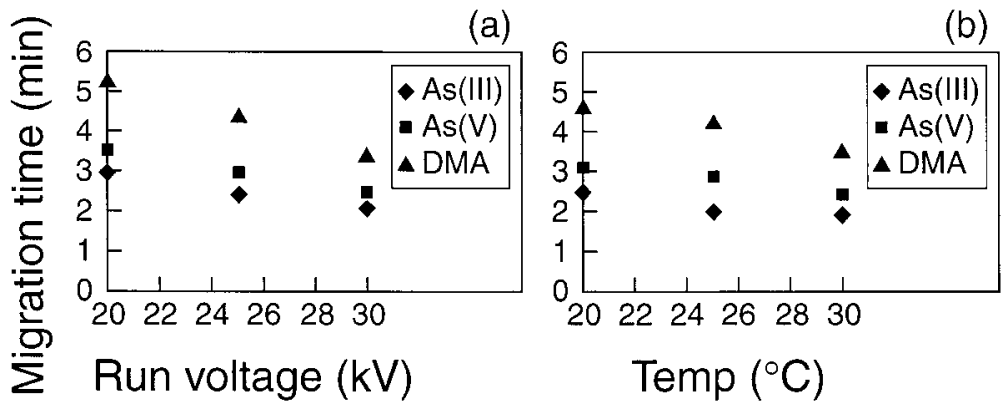

Fig. 2. Effect of runvoltage (a) and column temperature (b) on migration time of arsenic compounds. Separation column, 720-mm by 50- $\mu \mathrm{m}$

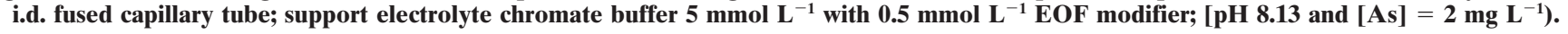




\section{Presence of Other Inorganic Anions}

Initial attempts to determine $\mathrm{As}(\mathrm{V})$ in soil solution, proved to be very difficult because of interferences from other anions in the soil solution. Samples of standard solutions consisting of a mixture of inorganic anions $(\mathrm{Cl}$, $\left.\mathrm{SO}_{4}, \mathrm{NO}_{3}, \mathrm{PO}_{4}\right)$ ranging in concentrations from 0 to $10 \mathrm{mg} \mathrm{L}^{-1}$ were injected at optimum conditions as described above. Chloride, $\mathrm{SO}_{4}$, and $\mathrm{NO}_{3}$ did not interfere with the As peaks, orthophosphate comigrated with the $\mathrm{As}(\mathrm{V})$ species. Further studies using standard solutions revealed that orthophosphate solutions exceeding $0.1 \mathrm{mg} \mathrm{L}^{-1}$ caused an unacceptable positive interference for the $\mathrm{As}(\mathrm{V})$ species. This posed problems for the analysis of As in soil water extracts, given that the concentration of phosphate in soil solutions often exceed $0.10 \mathrm{mg} \mathrm{L}^{-1}$.

Morin et al. (1992) found that at neutral or alkaline $\mathrm{pH}$ values for phosphate buffer solutions, the electrophoretic mobility of As species increased depending on the dissociation constant of the species. Examination of the $\mathrm{pK}_{\mathrm{a}}$ values of the phosphoric $\left(\mathrm{pK}_{\mathrm{a} 1}=2.13 ; \mathrm{pK}_{\mathrm{a} 2}=\right.$ 7.20; $\left.\mathrm{pK}_{\mathrm{a} 3}-12.36\right)$ and arsinic acid $\left(\mathrm{pK}_{\mathrm{a} 1}=2.19, \mathrm{pK}_{\mathrm{a} 2}=\right.$ $\left.6.94, \mathrm{pK}_{\mathrm{a} 3}=11.50\right)$ and the $\mathrm{pH}$-dissociation curves (not presented here) suggests that differences in the extent of dissociation of the two acids is greatest above $\mathrm{pH} 10$, possibly leading to variations in the migration times for these two anions. This is also consistent with the data in Fig. 4, which shows little difference in the mobilities of orthophosphate and $\mathrm{As}(\mathrm{V})$ at $\mathrm{pH}$ values 8.3, 9.2, and 10.0. When the carrier electrolyte $\mathrm{pH}$ exceeds 10 , orthophosphate migrates more rapidly than $\mathrm{As}(\mathrm{V})$. This is not surprising given that the largest difference in the dissociation of these acids is associated with its third dissociation constant.

Separation efficiency is a measure of the analyte zone broadening which occurs during the chromatographic (or electrophoretic) process. Plate theory models a separation as a series of discrete sections terms "theoretical plates". The higher the theoretical plate number, the more efficient is the separation and the sharper are the resulting peaks (Robards et al., 1994, p. 49). In CZE, the use of narrow diameter capillaries leads to a flat electroosmotic flow profile, which results in high separation efficiencies compared with pressure driven techniques, such as HPLC, which have a parabolic flow profile (Naidu et al., 1998). The separation efficiency in $\mathrm{CZE}$, in terms of the number of theoretical plates $(\mathrm{N})$, is given by:

$$
N=\mu V / 2 D
$$

where $\mu=$ analyte total mobility $\mathrm{cm}^{2} \mathrm{~V} \mathrm{~s}^{-1} ; V=$ applied voltage, in volts; and $D=$ solute diffusion coefficient, in $\mathrm{cm}^{2} \mathrm{~s}^{-1}$.

This suggests that the number of theoretical plates is directly proportional to the applied voltage. Investigation into the effect of buffer $\mathrm{pH}$ at varying run voltages and temperatures showed that $\mathrm{As}(\mathrm{V})$ and orthophosphate ions comigrate at a run voltage of $20 \mathrm{kV}$ at $20^{\circ} \mathrm{C}$ with a buffer $\mathrm{pH}$ of 8.13 (Fig. 5a). However, with increasing $\mathrm{pH}$, these two species gradually separate so that at $\mathrm{pH}$ 10.01, they are well resolved. On the basis of these

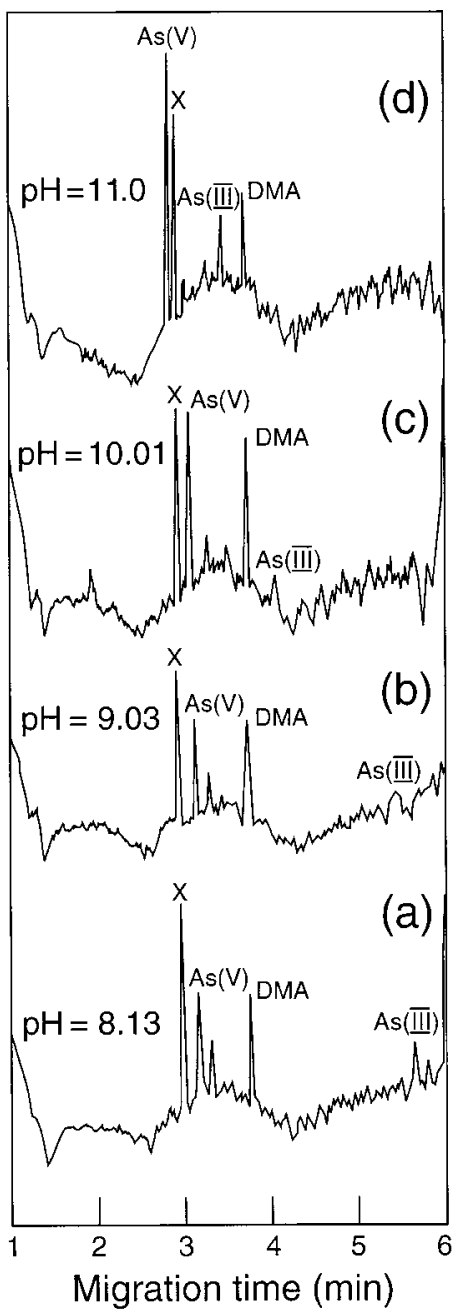

Fig. 3. Electropherograms of As species at different $\mathrm{pH}$ values using the operating conditions of $25 \mathrm{kV}, 30^{\circ} \mathrm{C}$ (verticle axis in $\mathrm{mV}$ ). Separation column, $720-\mathrm{mm}$ by $50-\mu \mathrm{m}$ i.d. fused capillary tube; support electrolyte chromate buffer $5 \mathrm{mmol} \mathrm{L}^{-1}$ with $0.5 \mathrm{mmol}$ $\mathrm{L}^{-1}$ EOF; $[\mathrm{As}]=2 \mathrm{mg} \mathrm{L}^{-1}$. Peak " $\mathrm{x}$ " was not identified during the analysis.

results, $\operatorname{As}(\mathrm{V})$ determination in soil solution can be best carried out using a $\mathrm{pH} 10$ chromate buffer with a run voltage of $20 \mathrm{kV}$ and a capillary temperature of $20^{\circ} \mathrm{C}$, while both DMA and As(III) are best analyzed using

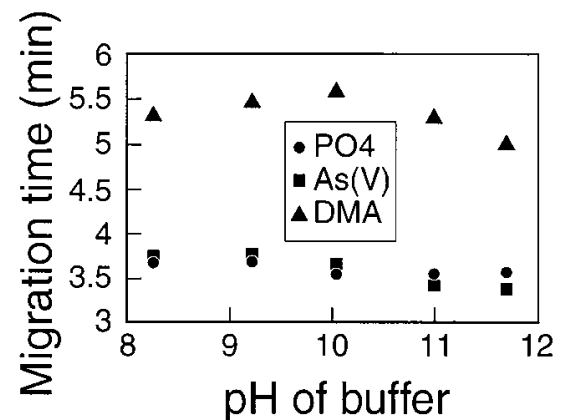

Fig. 4. Effect of $\mathrm{pH}$ of buffer solution on mean migration time of As(V) DMA and $\mathrm{PO}_{4}$ with the verticle axis in $\mathrm{mV}$. Separation column, $720-\mathrm{mm}$ by $50-\mu \mathrm{m}$ i.d. fused capillary tube; support electrolyte chromate buffer 5 mmol $\mathrm{L}^{-1}$ with $0.5 \mathrm{mmol} \mathrm{L}^{-1}$ EOF modifier; applied voltage $20 \mathrm{kV}$ ([As] and $[P]=2 \mathrm{mg} \mathrm{L}^{-1}$. 


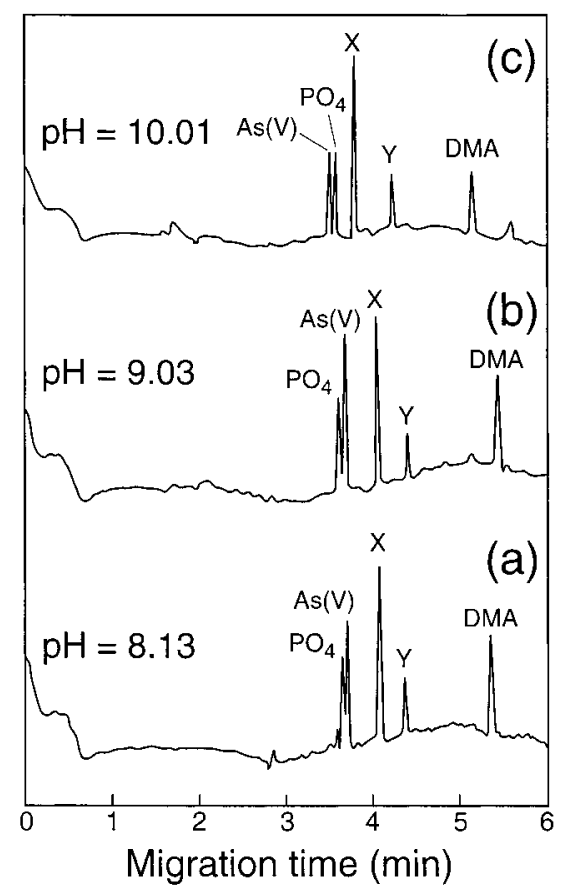

Fig. 5. Typical electropherograms of a soil solution at buffer $\mathrm{pH}$ values of 8.13 (a), 9.03 (b), and 10.01 (c). Separation column, 720-mm by $50-\mu \mathrm{m}$ i.d. fused capillary tube; support electrolyte chromate buffer $5 \mathrm{mmol} \mathrm{L}^{-1}$ with $0.5 \mathrm{mmol} \mathrm{L}^{-1}$ EOF modifier; applied voltage $20 \mathrm{kV}$, and $20^{\circ} \mathrm{C}$. Peaks " $\mathrm{x}$ " and " $\mathrm{y}$ " were not identified during the analysis.
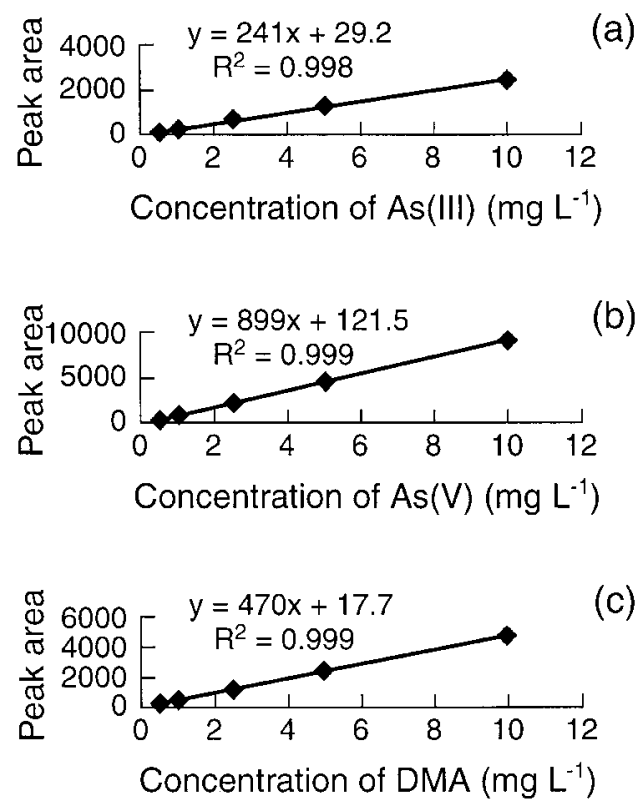

Fig. 6. Relationship between the concentration of As species and peak area. Separation column, $720-\mathrm{mm}$ by $50-\mu \mathrm{m}$ i.d. fused capillary tube; support electrolyte chromate buffer $5 \mathrm{mmol} \mathbf{L}^{-1}$ with $0.5 \mathrm{mmol} \mathrm{L}^{-1} \mathrm{EOF}$ modifier; applied voltage $25 \mathrm{kV}$ and $30^{\circ} \mathrm{C}$ for As(III) and DMA and $20 \mathrm{kV}$ and $20^{\circ} \mathrm{C}$ for $\mathrm{As}(\mathrm{V})$. pH of electrolyte for the separation of As(III) and DMA $=8.0$; pH of electrolyte separation of $\operatorname{As}(\mathbf{V})=10.0$.
Table 2. Mean percentage recovery of As species added to soil solution samples using the instrumental conditions developed.

\begin{tabular}{lcc}
\hline Nature of species & Amount added & Recovery \\
\hline \multirow{3}{*}{ As(III) } & mg L $^{-1}$ & $\%$ \\
& 2 & 85 \\
As(V) & 5 & 92 \\
DMA $\dagger$ & 2 & 100 \\
& 5 & 117 \\
& 5 & 94 \\
\end{tabular}

$\dagger$ DMA, dimethylarsinic acid.

a $\mathrm{pH} 8$ chromate-based buffer, a capillary temperature of $25^{\circ} \mathrm{C}$ and a run voltage of $30 \mathrm{kV}$.

\section{Calibration Curves}

Under the preferred conditions described above, plots of peak area and peak height against concentration were generated for the three As species (Fig. 6). The calibration curves based on peak area are linear with $R^{2}$ values $>0.99$, whereas the calibration curves obtained using peak heights are non linear at As concentrations above $1 \mathrm{mg} \mathrm{L}^{-1}$.

\section{Detection Limits}

The limit of detection of an analytical technique is generally evaluated from a knowledge of the standard deviation as a function of measurement level. A measured value is considered real when it is larger than the uncertainly associated with it. The point at which this occurs is defined arbitrarily as $3 \mathrm{~s}_{0}$, where $\mathrm{s}_{0}$ is the standard deviation of eight replicate measurements of the

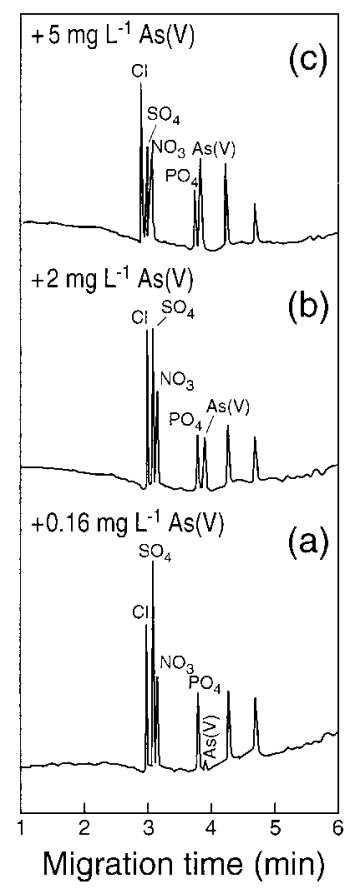

Fig. 7. Typical electropherograms of selected soil solutions following spiking of $\mathrm{As}(\mathrm{V})$ at $0.16,2$, and $5 \mathrm{mg} \mathrm{L}^{-1}$. Capillary conditions were identical to those developed above. Separation column, 720mm by $50-\mu \mathrm{m}$ i.d. fused capillary tube; support electrolyte chromate buffer 5 mmol $\mathrm{L}^{-1}$ with $0.5 \mathrm{mmol} \mathrm{L}^{-1}$ EOF modifier; applied voltage $20 \mathrm{kV}$ and $20^{\circ} \mathrm{C}$. $\mathrm{pH}$ of electrolyte separation of $\mathrm{As}(\mathrm{V})=10.0$. 
buffer solution. On the basis of this procedure, the limits of detection for As(V), DMA, and As(III) were calculated to be $0.10,0.10$, and $0.5 \mathrm{mg} \mathrm{L}^{-1}$, respectively.

\section{Recovery Tests}

Recovery tests were conducted with soil solutions $\left([\mathrm{As}(\mathrm{V})]=0.16 \mathrm{mg} \mathrm{L}^{-1}\right)$ that were spiked with varying concentrations of $\mathrm{As}(\mathrm{V}), \mathrm{As}(\mathrm{III})$, or DMA (Table 2). These studies revealed excellent agreement between the amounts of $\mathrm{As}(\mathrm{V}), \mathrm{As}(\mathrm{III})$, and DMA added to and recovered from soil solutions. An electropherogram typifying recovery data for $\mathrm{As}(\mathrm{V})$ is presented in Fig. 7. Between 85 and $117 \%$ of the added As species were recovered from the soil extracts with the highest recovery being for $\mathrm{As}(\mathrm{V})$ and the lowest for As(III). Similar recoveries were recorded with other soil solutions that were spiked with $\mathrm{As}(\mathrm{V})$.

\section{Natural Soil Water Samples}

Under the conditions developed above, As speciation was carried out in 25 soil solutions extracted from highly contaminated field moist soils. Typical electropherograms (Fig. 7) show peaks for As and other anions commonly found in soil solutions. However, apart from $\mathrm{As}(\mathrm{V})$, neither As(III) nor organoarsenic species were detected in the solutions isolated from field moist soils. With the exception of one soil solution, the concentration of $\mathrm{As}(\mathrm{V})$ was $<2 \mathrm{mg} \mathrm{L}^{-1}$. The exception was a highly alkaline soil $(\mathrm{pH}>12)$ in which soil solution As was $\sim 600 \mathrm{mg} \mathrm{L}^{-1}$. The total As content of the sample with soil solution As exceeding $600 \mathrm{mg} \mathrm{L}^{-1}$ was approximately $14000 \mathrm{mg} \mathrm{kg}^{-1}$ at a soil solution $\mathrm{pH}$ of 12.5 . Given that there is limited information in the literature on the maximum permissible soil solution concentrations of $\mathrm{As}(\mathrm{V})$, it is difficult to draw meaningful conclusions concerning the potential threat to soil biota, but potential for As leaching exists. Absence of As(III) and organoarsenic species in the soil solutions is not surprising since the presence of both is dependent on $\mathrm{Eh} / \mathrm{pH}$ conditions of the soil environment. Korte and Fernando (1991) report that arsenious species are stable under mildly reducing conditions and that the transition from As(V) to As(III) occurs at an Eh of $-115 \mathrm{mV}$ in soils with near neutral $\mathrm{pH}$. Although the $\mathrm{pH}$ values of some of the soils under study were close to neutral, all the soils were well aerated, which is not conducive to formation of organoarsenic species.

\section{Comparison with Hydride Generation}

Korte and Fernando (1991) report that the ideal method for the quantitative determination of As in solutions is the hydride generation atomic absorption spectrophotometric technique because it is simple, rapid, convenient, and has the necessary sensitivity for the determination of ultra low levels $\left(\mu \mathrm{g} \mathrm{L}^{-1}\right)$ of As. With this technique, As is converted to its hydride form followed by assay using atomic absorption spectrophotometry. Comparison of AAS generated data with CZE resulted in a 1:1 linear relationship with the $\mathrm{As}(\mathrm{V})$ data obtained using the CZE method $\left(R^{2}=0.989, P<0.001\right)$. Since the AAS method provides an indication of total As in soil solution irrespective of the nature of species, the observed close 1:1 relationship confirms that the predominant form of As in the soil solution studied is $\mathrm{As}(\mathrm{V})$ and also that CZE can be useful tool for the speciation of As.

\section{CONCLUSIONS}

Arsenic in natural samples is commonly estimated by either ICP-AES or hydride generation atomic absorption spectrophotometry. Neither of these methods provides a basis for direct speciation of As which may exist in natural systems as a variety of species. Alternatively, CZE appears to be an appropriate technique for the speciation of $\mathrm{AsO}_{3}^{3-}, \mathrm{AsO}_{4}^{3-}$, and DMA in soil solutions. The separation of these species was achieved by optimizing the $\mathrm{pH}$ of the chromate-based electrolyte, capillary temperature, and run voltage. The limits of detection for $\mathrm{As}(\mathrm{V}), \mathrm{DMA}$, and $\mathrm{As}(\mathrm{III})$ were found to be 0.10 , 0.10 , and $0.5 \mathrm{mg} \mathrm{L}^{-1}$, respectively, while recovery data indicate that between 85 to $117 \%$ of spiked As species were recovered from soil extracts samples.

\section{ACKNOWLEDGMENTS}

This research was supported by CSIRO Land and Water and Cooperative Research Centre for Soil and Land Management.

\section{REFERENCES}

Beauchemin, D., M.E. Bednas, S.S. Berman, J.W. McLaren, K.W.M Siu, and R.E. Sturgeon. 1988. Identification and quantitation of arsenic species in a dogfish muscle reference material for trace elements. Anal. Chem. 60:2209-2212.

Heckenberg, A.L., P.G. Alden, B.J. Wildman, J. Krol, J.P. Romano, P.E. Jackson, P. Jandik, and W.R. Jones. 1989. Waters innovative methods for ion analysis. Millipore Corporation, Marlborough, MA.

Hodgson, E., R.B. Mailman, and J.E. Chambers. 1988. Dictionary of toxicology. Macmillan, London.

Jackson, P.E., and P.R. Haddad. 1993. Capillary electrophoresis of inorganic ions and low-molecular-mass ionic solutes. Trends Anal. Chem. 12:231-238.

Jones, W.R., and P. Jandik. 1991. Controlled changes of selectivity in the separation of ions by capillary electrophoresis. J. Chromatogr. 546:445-458.

Jones, W.R., and P. Jandik. 1992. Various approaches to analysis of difficult sample matrices of anions using capillary ion electrophoresis. J. Chromatogr. 608:385-393.

Korte, N.E., and Q. Fernando. 1991. A review of arsenic (III) in groundwater. Crit. Rev. Environ. Contr. 21:1-39.

Laintz, K.E., J.J. Yu, and C.M. Wai. 1992a. Separation of metal ions with sodium bis(trifluoroethyl) dithio-carbamate chelation and supercritical fluid chromatography. Anal. Chem. 64:311-315.

Laintz, K.E., J.M. Sjieh, and C.M. Wai. 1992b. Simultaneous determination of arsenic and antimony species in environmental samples using bis (trifluoroethyl) dilhocarbanate chelation and supercritical fluid chromatography. J. Chromatogr. Sci. 30:120-123.

Morin, P., M.B. Amran, S. Favier, R. Heimburger, and M. Leroy. 1992. Separation of arsenic anions by capillary zone electrophoresis with UV detection. Fresenius J. Anal. Chem. 342:357-362.

Naidu, R. 1996. Application of capillary electrophoretic analytical technique to anion speciation and analyses in natural systems. p. 197-198. In Proceedings of Australian and New Zealand National Soils Conference, Melbourne 1-4 July. Australian Society of Soil Science, Melbourne, Australia. 
Naidu, R., S. Naidu, P. Jackson, R.G. McLaren, and M.E. Sumner. 1998. Application of capillary electrophoresis to anion speciation in soil water extracts: I. Theory and Principles. Adv. Agron. 65: $131-150$.

Robards, K., P.R. Haddad, and P.E. Jackson. 1994. Principles and practice of modern chromatographic methods. Academic Press, London.

Sheppard, B.S., J.A. Carusa, D.T. Heitkemper, and K.A. Wolnik. 1992. Arsenic speciation by ion chromatography with inductively coupled plasma mass spectrometric detection. Analyst 117:971-975.
Thompson, J.J., and R.S. Houk. 1986. Inductively coupled plasma mass spectrometic detection for multielement flow injection analysis and elemental speciation by reverse phase liquid chromatography. Anal. Chem. 58:2541-2548.

Voth-Beach, L.M., and D.E. Shrader. 1985. Reduction of interferences in the determination of arsenic and selenium by hydride generation. Spectroscopy 1:60-65.

Wildman, W.J., P.E. Jackson, W.R. Jones, and P.G. Alden. 1991. Analysis of anion constituents of urine by inorganic capillary electrophoresis. J. Chromatogr. 546:459-466.

\title{
Modeling Arsenic(III) Adsorption and Heterogeneous Oxidation Kinetics in Soils
}

\author{
Bruce A. Manning* and Donald L. Suarez
}

\begin{abstract}
Arsenite [As(III)] is a soluble and toxic species of arsenic that can be introduced into soil by geothermal waters, mining activities, irrigation practices, and disposal of industrial wastes. We determined the rates of $\mathbf{A s}$ (III) adsorption, and subsequent oxidation to arsenate $[A s(V)]$ in aerobic soil-water suspensions using four California soils. The rate of As(III) adsorption on the soils was closely dependent on soil properties that reflect the reactivity of mineral surfaces including citrate-dithionite (CD) extractable metals, soil texture, specific surface area, and pH. Heterogeneous oxidation of $\mathrm{As}(\mathrm{III})$ to $\mathrm{As}(\mathrm{V})$ was observed in all soils studied. The recovery of $\mathrm{As}(\mathrm{V})$ from $\mathrm{As}(\mathrm{III})$ treated soils was dependent on levels of oxalate-extractable Mn and soil texture. After derivation of rate equations to describe the changes in soluble and recoverable $\mathbf{A s}(\mathrm{III})$ and $\mathrm{As}(\mathrm{V})$ in soil suspensions, soil property measurements were used to normalize the empirically derived rate constants for three soils. The fourth soil, which had substantially different soil properties from the other three soils, was used to independently test the derived soil property-normalized model. The soil property-normalized consecutive reaction model gave a satisfactory description of the trends seen in the experimental data for all four soils. Understanding the effects of soil properties on the kinetics of chemical reactions of $\mathrm{As}(\mathrm{III})$ and $\mathrm{As}(\mathrm{V})$ in soils will be essential to development of quantitative models for predicting the mobility of As in the field.
\end{abstract}

$\mathrm{T}$ HE OXIDATION of trace metals and metalloid oxyanions by soils has an important role in determining their mobility and toxicity. Reduced species such as $\mathrm{As}(\mathrm{III}), \mathrm{Se}(\mathrm{IV})$, and $\mathrm{Cr}$ (III) can be oxidized in soils to produce $\mathrm{As}(\mathrm{V}), \mathrm{Se}(\mathrm{VI})$, and $\mathrm{Cr}(\mathrm{VI})$, respectively. In the case of Se and $\mathrm{Cr}$, the oxidized $\mathrm{Se}(\mathrm{VI})$ and $\mathrm{Cr}(\mathrm{VI})$ species are less strongly adsorbed to soils than Se(IV) and $\mathrm{Cr}(\mathrm{III})$ and thus are more mobile and bioavailable. The oxidation of $\mathrm{As}(\mathrm{III})$ produces $\mathrm{As}(\mathrm{V})$, which is strongly adsorbed in soils and is less toxic than As(III) (Knowles and Benson, 1983). Despite the fact that the reactions of As(III) with soil have been studied, the rates and mechanisms of As(III) adsorption, as well as oxidation to $\mathrm{As}(\mathrm{V})$, are still not well understood. The As(III) species can also be present in groundwater (Korte and

Bruce A. Manning, Dep. of Chem. and Biochem., San Francisco State Univ., 1600 Holloway Ave., San Francisco, CA 94132; and Donald L. Suarez, USDA-ARS, U.S. Salinity Lab., 450 W. Big Springs Rd., Riverside, CA 92507-4617. Contribution from the USDA-ARS U.S. Salinity Lab. Received 19 Aug. 1998. *Corresponding author (bmanning@sfsu.edu).

Published in Soil Sci. Soc. Am. J. 64:128-137 (2000).
Fernando, 1991), and therefore the stability of As(III) after coming in contact with aerobic soils is of interest in environmental management.

Previous work on the reactions of As(III) with soil has focused primarily on As(III) adsorption rather than As(III) oxidation (Manning and Goldberg, 1997a; McGeehan and Naylor, 1994; Elkhatib et al., 1984). Iron oxides have been shown to be the most important mineral component in determining a soil's overall capacity to adsorb As(III) and As(V) (Jacobs et al., 1970; Fordham and Norrish, 1974, 1979; Elkhatib et al., 1984; Livesey and Huang, 1981; Manning and Goldberg, 1997a). It has also been concluded, using x-ray absorption spectroscopy (XAS), that $\mathrm{As}(\mathrm{V})$ is specifically adsorbed on synthetic Fe(III) oxide mineral surfaces (Waychunas et al., 1993; Fendorf et al., 1997). Electrophoretic mobility work (Pierce and Moore, 1982) has shown that As(III) is also specifically adsorbed on the $\mathrm{Fe}(\mathrm{III})$ oxide surface, and this has now been confirmed using Fourier transform infrared spectroscopy (Sun and Doner, 1996) and XAS (Manning et al., 1998).

The oxidation of $\mathrm{As}(\mathrm{III})$ to $\mathrm{As}(\mathrm{V})$ in soils has not been extensively studied despite the fact that this is an important reaction in the cycling of As in the environment. The oxidation of As(III) by lake sediments has been investigated (Oscarson et al., 1980, 1981) and it was concluded that an abiotic process involving $\mathrm{Mn}$ oxide minerals was directly responsible for As(III) oxidation. Heterogeneous oxidation of As(III) by synthetic Mn oxides (Oscarson et al., 1983; Scott and Morgan, 1995; Sun and Doner, 1998), and clay minerals (Manning and Goldberg, 1997b) has been shown, though very little is known about the rates or mechanisms of As(III) oxidation in whole soils. An improved understanding of the rate of As(III) oxidation in whole soil is necessary for the application of predictive models to describe As transport in the field. In addition, linking measurements of important soil properties with a quantitative description of $\mathrm{As}(\mathrm{III})$ adsorption and oxidation would improve the predictive capability of reactive transport models.

Given the need for a better understanding of the

Abbreviations: CD, citrate-dithionite; DI, deionized; HPLCHGAAS, high performance liquid chromatography-hydride generation atomic absorption spectrometry; $\mathrm{Me}_{\mathrm{T}}$, total citrate-dithionite extractable metals $(\mathrm{Al}+\mathrm{Fe}+\mathrm{Mn}) ; \mathrm{Mn}_{\mathrm{OX}}$, oxalate-extractable manganese; SA, specific surface area; XAS, $x$-ray absorption spectroscopy; XRD, x-ray diffraction. 